\title{
TÖMBELEKTRÓDÁS SZIKRAFORGÁCSOLÁS KÍSÉRLETI VIZSGÁLATA MIKROGEOMETRIAI JELLEMZÖK ALAPJÁN
}

\author{
Fekete Vivien \\ egyetemi hallgató, Miskolci Egyetem, Gyártástudományi Intézet \\ 3515 Miskolc, Miskolc-Egyetemváros, e-mail:fvvivien03@gmail.com \\ Maros Zsolt \\ egyetemi docens, Miskolci Egyetem, Gyártástudományi Intézet \\ 3515 Miskolc, Miskolc-Egyetemváros, e-mail: zsolt.maros@uni-miskolc.hu
}

\begin{abstract}
Absztrakt
Szikraforgácsoláskor a megmunkált felület érdessége rendkívül fontos szerepet játszik az adott eljárás alkalmazhatósága szempontjából. Az alábbi cikkben a tömbelektródás szikraforgácsolás jellegzetes elektróda anyagainak (réz és grafit) összehasonlitó vizsgálatával foglalkozunk a megmunkált felületek érdessége és az anyagleválasztási teljesitmény alapján. Az összehasonlitás alapját a szikraforgácsolt felület különbözö mikrogeometriai jellemzöi, ezen belül is a felületi érdesség amplitúdó paraméterei adják. Kutatásunk célja, megválaszolni, hogy melyik szerszámanyaggal állitható elö jobb felületminöség. Az elvégzett forgácsolási kisérletek majd az azt követö mérések alapján összességében a grafit elektróda (szerszám) kedvezöbb tulajdonságokat mutat mind a leválasztás hatékonysága, mind a megmunkált felületek érdességi jellemzöi alapján.
\end{abstract}

Kulcsszavak: szikraforgácsolás, felületi érdesség, grafit és réz szerszámanyag

\section{Abstract}

The roughness of the machined surface plays an extremely important role in the given process at electro discharge machining. A comparative study of the characteristic electrode materials (copper and graphite) of die-sink electro discharge machining (EDM) is accomplished in this paper based on the roughness of the machined surfaces and the material removal rate. The comparison is based on the different microgeometric characteristics of the machined surfaces, including the amplitude parameters of the surface roughness. The aim of the research is to answer with which tool material can be machined better surface quality. Based on the performed cutting experiments and the subsequent measurements, the graphite electrode (tool) shows more favourable properties based on both the efficiency of material removal and the roughness characteristics of the machined surfaces.

Keywords: electro discharge machining, surface roughness, graphite and copper tool material

\section{Bevezetés}

A megmunkálandó anyagok fejlődésének köszönhetően, az iparban egyre nagyobb keménységü, szilárdságú anyagokkal kezdtek el dolgozni, amelyeket a hagyományos módszerekkel rendkívül nehéz lenne vagy egyáltalán nem is lehet megmunkálni. Ennek hatására születtek meg a különböző különleges megmunkálások, melyek közül az egyik legjelentősebb eljárás a szikraforgácsolás (Hhos et al., 2004). Villamosan vezető, nagy keménységü anyagok megmunkálására alkalmas, tömbelektródás eljárása térbeli felületek kialakítását teszi lehetővé. Közkedvelt alkalmazási területe a szerszámgyártás. 
A különböző szerszámanyagok vizsgálatával több irodalom is foglalkozik, közöttük réz, bronz és grafit elektródákkal egyaránt (Khan, 2008; D’Urso et al., 2016; Aas, 2004). Az (Amorim Walter és Weingaertner, 2007) irodalom grafit és réz elektródák összehasonlítását mutatja be az anyagleválasztás hatékonyságát elemezve. Cikkünkben a réz és grafit elektródák elsősorban a megmunkált felületek érdessége alapján végzett összehasonlítását tủztük ki célul. A szakirodalomban többen is foglalkoztak már a szikraforgácsolt felületek érdességével a technológiai adatok függvényében (Puertas et al., 2004; Lee és Li, 2001). Jelen cikkben, réz és grafit elektródával szikrázott felületek mikrogeometriai jellemzőinek vizsgálata során kapott kutatási eredményeinket prezentáljuk.

A szikraforgácsolt felület egymást átfedő, szabálytalanul elhelyezkedő kráterekből épül fel (1. ábra), melyek kialakulását számos technológiai paraméter - pl. feszültség, áramerősség, ciklusidő - befolyásolja (Hhos et al., 2004). A mai korszerủ szerszámgépek alkalmazásakor, ezen paraméterek jó részét a szerszámgép automatikusan generálja és a megmunkálás szempontjából optimális értékre állítja. A szikraforgácsoló berendezéseken, az optimalizálás alapjául a VDI fokozat szolgál, melyet a gépkezelő állít be a megmunkálás kezdete előtt. A VDI a Német Mérnöki Kamara rövidítése (Verein Deutscher Ingenieure). Ez a szervezet szabvány jellegü müszaki ajánlásokat dolgoz ki a különböző müszaki folyamatok és problémák megoldásának elősegítésére. A VDI 3400-as szabvány a szikraforgácsolással foglalkozik. Ez az ajánlás, a megmunkált felületeket a felületi érdesség alapján úgynevezett VDI fokozatokba csoportosítja VDI 00-tól VDI 45-ös értékig. Ennek célja az alkatrészek felületi jellemzőinek standardizálása, ami elengedhetetlen szempont a mérnökök számára a szikraforgácsolással gyártott fröccsöntő formabetétek tervezéséhez. Napjainkban a VDI skála világszerte alkalmazott a szerszámgyártásban. A paraméter egyfajta felület érdességi jellemző és az általános felületi érdességi mérőszámokat egészíti ki.

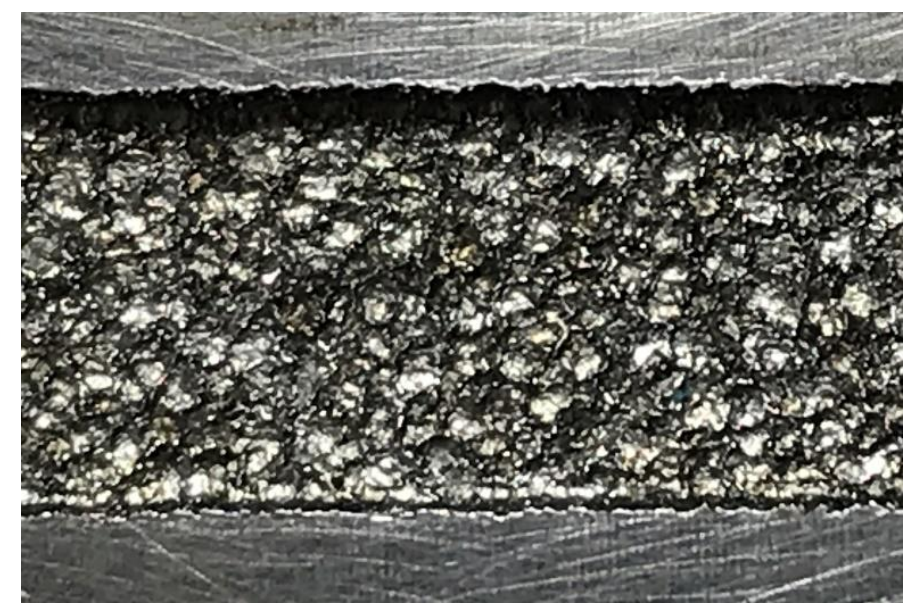

1. ábra. Szikraforgácsolt felület mikroszerkezete

Az érdességi paraméterek változását, a megmunkálás VDI fokozatának függvényében vizsgáltuk. Hasonló vizsgálatokról a (Mikó et al., 2014) irodalomban számoltak be. A kísérletek kivitelezését és a mérési eredményeinket a továbbiakban ismertetjük.

\section{Kísérleti körülmények}

A kísérlet során St37-2K (S235JRC) jelü ötvözetlen szerkezeti acél felületét munkáltuk meg tömbelektródás szikraforgácsolással. A próbadarab egy 100 x 120 x 20 mm nagyságú, téglalap keresztmetszetü, 
hőkezeletlen lemez volt, melynek felületét a hatékonyabb szikrázás érdekében előzetesen megköszörültük.

\subsection{A kísérletekhez használt szerszámgép és az alkalmazott mérőberendezés jellemzői}

A szikrázási kísérleteket egy OPS-Ingersoll GANTRY 400 típusú tömb-szikraforgácsoló gépen végeztük. A megmunkálás során a munkadarab befogása satuban történt.

A megmunkált felületek érdességmérését a Miskolci Egyetem Gyártástudományi Intézetének Érdesség és kopásmérő laboratóriumában végeztük el az AltiSurf 520 háromdimenziós felülettopográfiai berendezésen. A mérések során, a grafit elektródával készült üregek esetében - a keskenyebb méretü üregek miatt $-6 \mathrm{db}$ mérési helyet, a réz elektróda esetében $9 \mathrm{db}$ mérési helyet vizsgáltunk. Ehhez a méröberendezés LK-G32 lézeres mérőfejét használtuk. Minden mérést $1=12,5 \mathrm{~mm}$ hosszon végeztünk, a szürési paramétert (cut-off) 2,5 mm-re állítottuk be.

\subsection{Szerszámelektródák}

A megmunkálás alkalmával 5-5 különböző felületi érdességü, egymástól egyenlő távolságra elhelyezkedő üreget készítettünk, grafit és réz elektródákkal, melyek a munkadarab két különböző oldalán helyezkednek el (2. ábra).

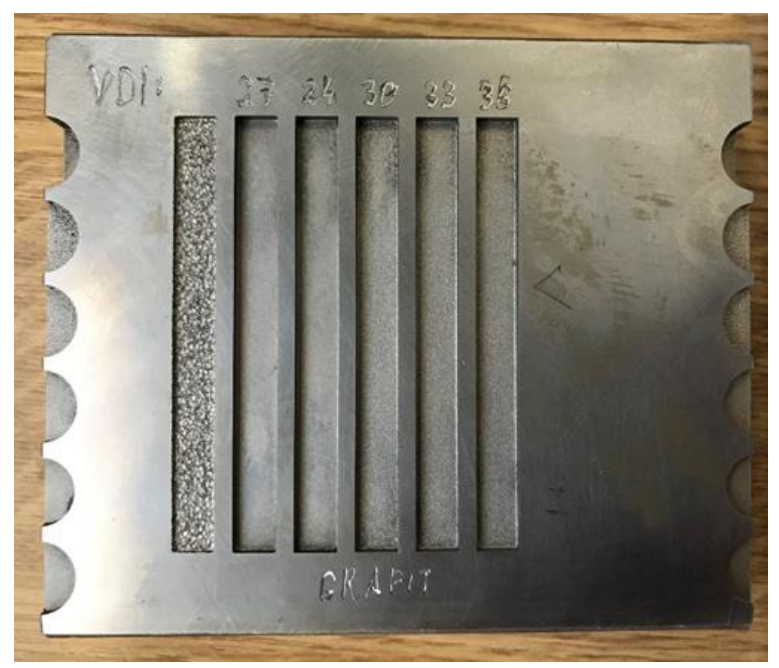

a)

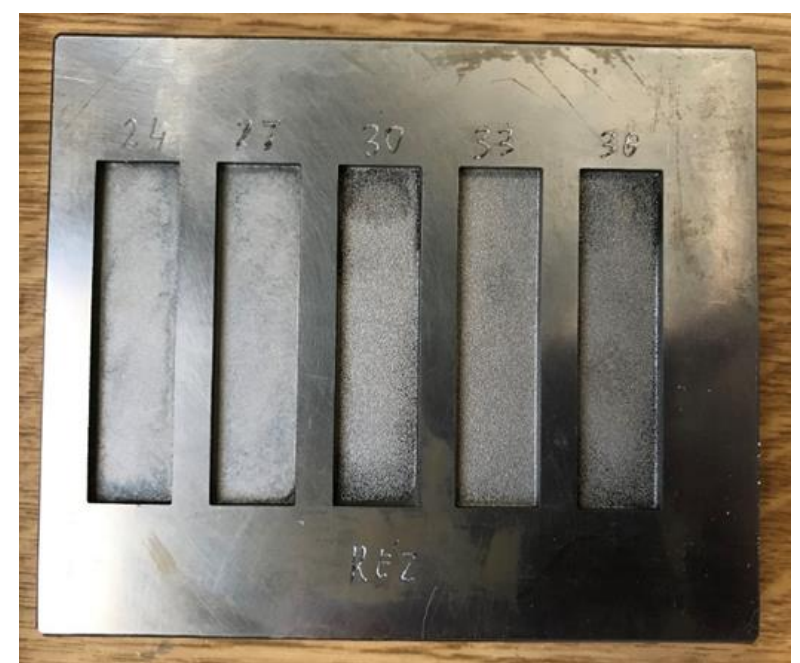

b)

\section{2. ábra. A kisérleti darab bemutatása}

a) grafittal készült üregek b) rézzel készült üregek

Az alkalmazott grafit elektróda keresztmetszete 71,5 x 6,5 mm, a réz elektródáé 56 x 13 mm (3. ábra). 


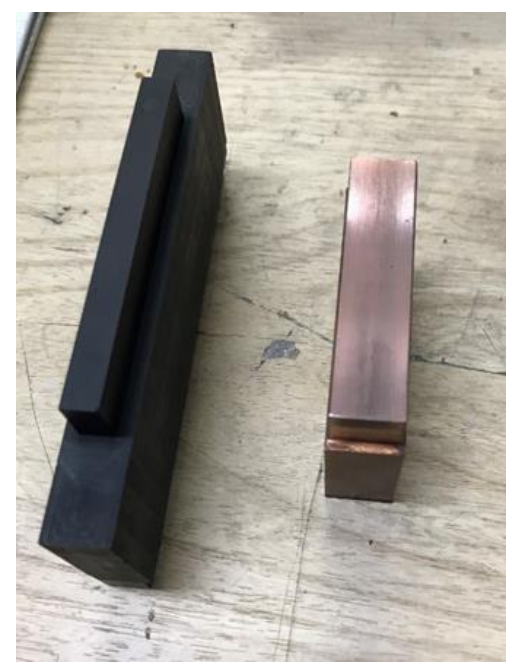

3. ábra. Az alkalmazott grafit és réz elektróda

\subsection{A szikrázási kísérletek kivitelezése}

A szikraforgácsolt üregek VDI 24, 27, 30, 33, 36-os fokozattal készültek, négyszögletes bővítés alkalmazása mellett. Mindkét szerszámanyag vonatkozásában egy elektródát alkalmaztunk. A szikraközt 0,3 mm-re, a szikrázási mélységet $2 \mathrm{~mm}$-re állítottuk be, melyeket ezután a teljes müvelet során állandó értéken tartottunk. A megmunkáláshoz szükséges egyéb paramétereket a szerszámgép automatikusan állítja be, a munkadarab és az elektróda anyaga, a kívánt felületi érdesség (VDI fokozat), a szikraköz, a szikrázási mélység és a megmunkált felület területe alapján.

\section{Kísérleti eredmények kiértékelése}

A szikraforgácsolási kísérlet elvégzése után, megvizsgáltuk a megmunkált felületek különböző mikrogeometriai jellemzőit. A kétféle szerszámanyagot a felületi érdesség jellegzetes amplitúdó paramétereinek $\left(\mathrm{R}_{\mathrm{a}}, \mathrm{R}_{\mathrm{z}}\right)$ vonatkozásában hasonlítottuk össze.

A 4. ábra a kétféle elektróda anyaggal szikrázott felületek átlagos érdességének $\left(\mathrm{R}_{\mathrm{a}}\right)$ alakulását mutatja a VDI paraméter függvényében. A szakirodalom szerint, a VDI fokozatok növelésével egyre durvább felületminőséget állítunk elő, azonban a 4. ábra szerint, a mérési eredmények nem teljesen igazolják ezt. Mindkét anyag esetében elmondható, hogy a VDI 24 és 27, valamint a VDI 30-36 minőségi fokozatok között csekély a felületi érdesség különbség, de a két intervallum jelentősen eltér egymástól. Megfigyelhető továbbá, hogy a VDI 30-as fokozatnál hirtelen felületminőség romlás következik be, ami miatt ez a felület rendelkezik a legrosszabb tulajdonságokkal. Összevetve a két elektróda anyagot, elmondható, hogy a grafittal készült felületek átlagos érdessége a kedvezőbb. 


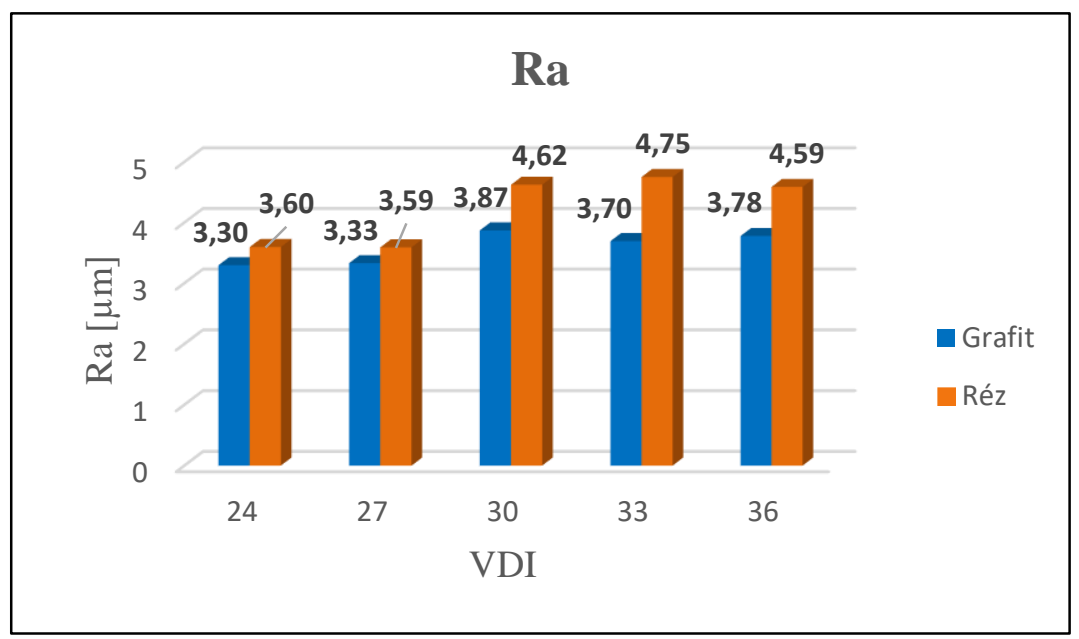

4. ábra. $R_{a}$ paraméter változása a VDI függvényében

Az 5. ábra az $R_{z}$ egyenetlenség magasság változását írja le a VDI fokozatok függvényében. A kapott mérési eredmények alapján elmondható, hogy $R_{z}$ értékei $R_{a}$ értékeivel analóg módon változnak és ezen paraméter tekintetében is kijelenthető, hogy a grafit szerszám eredményezett kedvezőbb felületminőséget. A 4. és 5. ábra szerint, a szikraforgácsolt felületeknél is összefüggés látszik az egyenetlenség magasság és az átlagos érdesség között. A két paraméter aránya kb 6-8 között változik, ami hasonló jelleget mutat, mint a szakirodalomban forgácsolt felületekre közölt $\mathrm{R}_{\mathrm{z}} \approx(4 \div 6) \mathrm{R}_{\mathrm{a}}$ összefüggések (Sedlacek et al., 2011; Asiltürk et al., 2016).

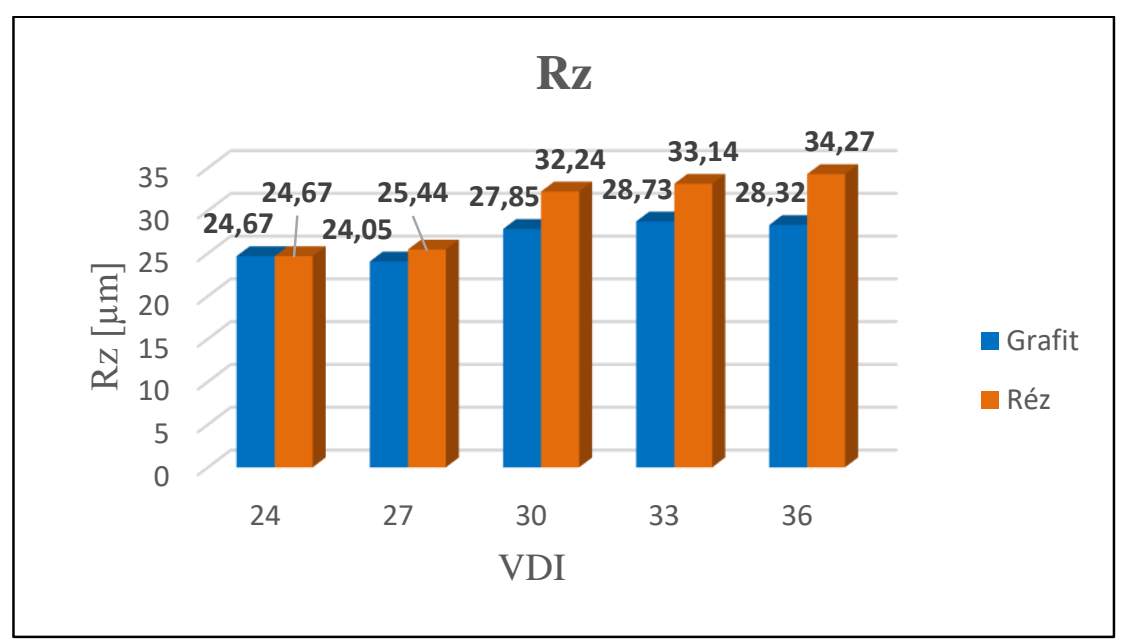

5. ábra. $R_{z}$ paraméter változása a VDI függvényében

Az eddigi megállapításokon felül megvizsgáltuk, hogy a megmunkált felületek tényleges érdessége mennyire egyezik a gépi adatok szerinti, VDI fokozatok által garantált felületi érdességgel. A VDI fokozatok $R_{\mathrm{a}}$ értékeit a VDI 3400 szabvány táblázatai alapján állapíthatjuk meg. A vizsgálat eredményét a 6. ábra prezentálja mindkét elektróda anyagra vonatkoztatva. Az irodalom szerint elóírt VDI fokozatok 
$\mathrm{R}_{\mathrm{a}}$ értékei exponenciális növekedést mutatnak. Ezzel szemben a mért értékek által leírt görbék lineárisak. Ebből arra következtethetünk, hogy az általunk használt szerszámgép már nem megfelelően képes hozni a kívánt felületminőséget. A két anyag tekintetében, az ábra alapján megállapítható, hogy a VDI 24-es, 27-es és 30-as fokozaton a grafit, a 33-as és 36-os fokozaton a réz áll közelebb az elöírt értékhez.

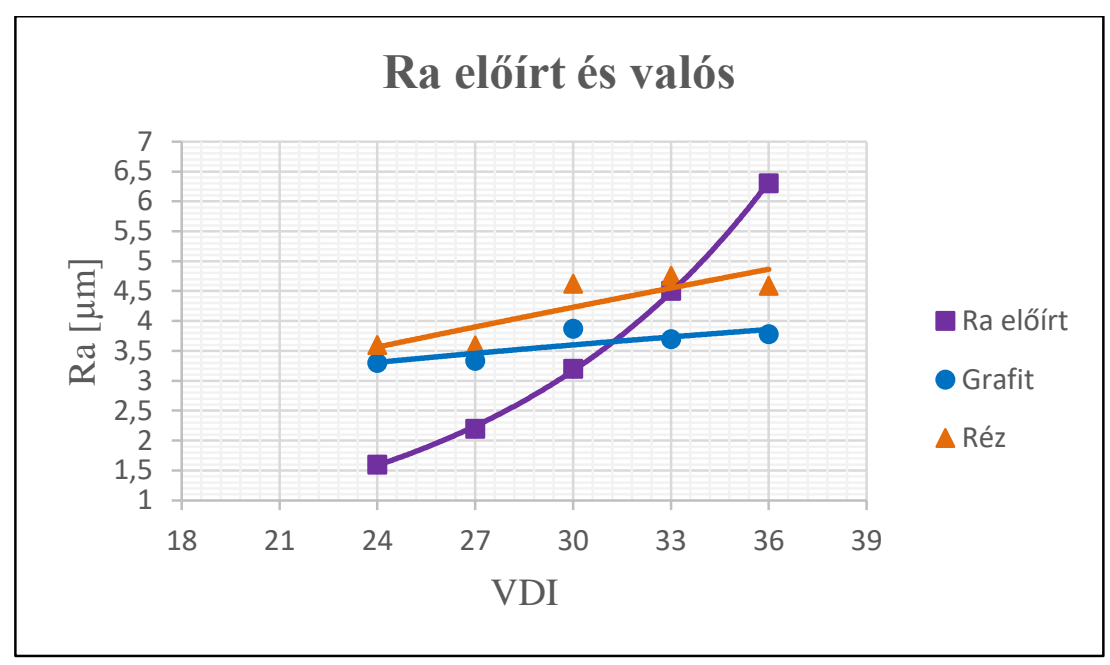

6. ábra. Az Ra paraméter elöirt és tényleges értékeinek összehasonlitása

\section{4. Összefoglalás}

Az eredményeket összegezve, a kétféle szikraforgácsoló szerszám elektróda anyag (grafit, réz) összehasonlítására irányuló kísérletek alapján az alábbi megállapítások tehetők:

- Az amplitúdó jellegü érdességi paraméterek $\left(R_{a}\right.$ és $\left.R_{z}\right)$ tekintetében, a vizsgált tartományban és körülmények között, a grafit szerszám minden esetben kedvezöbb átlagos felületi érdességet $\left(\mathrm{R}_{\mathrm{a}}\right)$ és egyenetlenség magasságot $\left(R_{z}\right)$ eredményezett, mint a réz. A mért értékek az $R_{a}=3,3-4,7 \mu \mathrm{m}$, $\mathrm{R}_{\mathrm{z}}=24-34,3 \mu \mathrm{m}$ tartományban mozogtak.

- A VDI 24 és 27, valamint a VDI 30-36 minőségi fokozatok között alig van eltérés, de a két intervallum jelentősen eltér egymástól. Kimondottan ugrás (az érdesség romlása) észlelhető a VDI 30as fokozatnál.

- A gépi adatok szerinti, VDI fokozatok által garantált felületi érdességi paraméterek VDI 33 fokozatig minden esetben kisebbek, mint a ténylegesen megmunkált felületek mért érdessége. VDI 36 fokozatnál már a tényleges érték kisebb a garantáltnál.

- Az egyenetlenség magasság $\left(\mathrm{R}_{\mathrm{z}}\right)$ változása minden esetben az $\mathrm{R}_{\mathrm{a}}$ átlagos érdességgel analóg módon változik és az esztergált felületekhez hasonlóan szikraforgácsolásnál $R_{z} \approx(6 \div 8) R_{a}$ arányt tapasztaltunk.

Összességében elmondható, hogy a grafit szerszámanyag a megmunkált felületek érdességét tekintve kedvezőbb, mint a réz elektróda. A VDI fokozatokat illetően 24-27, illetve 30-36 fokozatok között minimális a különbség. Feltűnő továbbá, hogy a vizsgált paraméterek tekintetében VDI 30-as fokozatnál egy ugrás történik, vagyis ezt a fokozatot nem célszerú alkalmazni. Eredményeink alapján, jó felületi érdesség eléréséhez ajánlható tehát a grafit szerszám alkalmazása VDI 24 vagy 27 fokozatok alkalmazása mellett. Mivel a megmunkált felületeken mért tényleges érdességek és a szerszámgép által garantált felületi érdesség nagyfokú eltérést mutat, szükséges lehet a gép müszaki felülvizsgálata. 


\section{Irodalom}

[1] HHoS, K., Newman, T., Rahimifard, S., Allen, RD. (2004). State of the art in wire electrical discharge machining (WEDM). International Journal of Machine Tools and Manufacture, 44(12-13), 1247-1259. https://doi.org/10.1016/j.ijmachtools.2004.04.017

[2] Khan, A. A. (2008). Electrode wear and material removal rate during EDM of aluminum and mild steel using copper and brass electrodes. Int J Adv Manuf Technol, 39, 482-487. https://doi.org/10.1007/s00170-007-1241-3

[3] D’Urso, G., Maccarini, G. \& Ravasio, C. (2016). Influence of electrode material in micro-EDM drilling of stainless steel and tungsten carbide. Int J Adv Manuf Technol, 85, 2013-2025. https://doi.org/10.1007/s00170-015-7010-9

[4] Aas, K. L. (2004). Performance of two graphite electrode qualities in EDM of seal slots in a jet engine turbine vane. Journal of Materials Processing Technology, 149(1-3), 152-156. ISSN 0924-0136. https://doi.org/10.1016/j.jmatprotec.2004.02.005

[5] Amorim Walter, F. L., Weingaertner, L. (2007). The behavior of graphite and copper electrodes on the finish die-sinking electrical discharge machining (EDM) of AISI P20 tool steel. J. Braz. Soc. Mech. Sci. \& Eng., 29(4). https://doi.org/10.1590/S1678-58782007000400004

[6] Puertas, I., Luis, C. J., Alvarez, L. (2004). Analysis of the influence of EDM parameters on surface quality, MRR and EW of WC-Co. Journal of Materials Processing Technology, 153-154, 1026-1032. https://doi.org/10.1016/j.jmatprotec.2004.04.346

[7] Lee, S. H., Li, X. P. (2001). Study of the effect of machining parameters on the machining characteristics in electrical discharge machining of tungsten carbide. Journal of Materials Processing Technology, 115, 344-358. https://doi.org/10.1016/S0924-0136(01)00992-X

[8] Mikó, B., Drégelyi-Kiss, Á., Poór, A. (2014). Study of surface quality and electrode wear in EDM technology. In: W, Zebala, I., Mankova (Eds.), Development in Machining Technology (pp. 194-211). Cracow, Lengyelország: Cracow University of Technology Tadeusz Kosciuszko.

[9] Sedlacek, M, Podgornik, B, Vizintin, J. (2011). Correlation between standard roughness parameters skewness and kurtosis and tribological behaviour of contact surfaces. Tribol Int., 48, 102112. https://doi.org/10.1016/j.triboint.2011.11.008

[10] Asiltürk, I., Neşeli, S., Alper İnce, M. (2016). Optimisation of parameters affecting surface roughness of Co28Cr6Mo medical material during CNC lathe machining by using the Taguchi and RSM methods. Measurement, 78, 120-128. https://doi.org/10.1016/j.measurement.2015.09.052 